\title{
MEWADAHI COMMUNITY BASED TOURISM DALAM COMMUNITY GROUP UNTUK PENGEMBANGAN INDUSTRI PARIWISATA
}

\author{
Suhartanto \\ Jurusan Pendidikan Administrasi, Fakultas Ilmu Ekonomi, Universitas Negeri Yogyakarta, Indonesia \\ suhartanto1992@uny.ac.id
}

\begin{abstract}
Abstrak: Mewadahi Community Based Tourism dalam Community Group untuk Pengembangan Industri Pariwisata. Pengembangan industri pariwisata diarahkan pada pariwisata berbasis masyarakat (community based tourism). Penelitian ini bertujuan untuk menganalisis community based tourism dalam wadah community group untuk pengembangan industri pariwisata. Penelitian ini merupakan jenis penelitian kualitatif dengan menggunakan pendekatan deskriptif. Sumber data penelitian adalah data sekunder, berupa buku, jurnal, news (cetak/digital), regulation, dan dokumen-dokumen lain yang mendukung. Analisis data menggunakan tahapan pengumpulan data, kondensasi data, penyajian data dan penarikan kesimpulan. Hasil penelitian ini menunjukan bahwa pengembangan industri pariwisata berbasis community based tourism diterapkan di pedesaan dalam bentuk desa wisata. Community based tourism membutuhkan partisipasi masyarakat dari mulai perencanaan, implementasi dan evaluasi. Agar pembangunan industri pariwisata dalam bentuk desa wisata efektif dan efisien, community based tourism diwadahi dalam community group, sehingga penyerapan partisipasi masyarakat dalam satuan community dapat diangkat dalam wadah group untuk mencapai tujuan bersama.
\end{abstract}

Kata kunci: Community, Based, Tourism,Community, Group

\begin{abstract}
Organizing Community Based Tourism in the Community Group for the Development of the Tourism Industry. The development of the tourism industry is directed at community-based tourism. The aim of this study is to analyze community based tourism in a community group forum for the development of the tourism industry. The type of this research is a qualitative research that use a descriptive approachment. The data source of this research are secondary data, books, journals, news (print / digital), regulation, and others. The stages of data analysis is used data collection, data condensation, data presentation and drawing conclusions. The results of this study indicate that the development of a community-based tourism industry based on tourism is implemented in rural areas in the form of a tourism village. Community based tourism were required community participation from planning, implementation and evaluation. So, the development of the tourism industry in this form can be effective and efficient, community based tourism must accommodated in a community group. The absorption of community participation in community units can be raised in a group to achieve its purpose.
\end{abstract}

Keyword: Community, Based, Tourism,Community, Group

\section{PENDAHULUAN}

Indonesia memiliki bentang alam yang indah (natural resources) dan kebudayaan yang beragam (cultural resources) sebagai modal pengembangan industri pariwisata. Natural dan cultural resources dikemas dalam satu paket wisata, menjadi potensi wisata baru untuk menarik wisatawan mancanegara (wisman) dan wisatawan nusantara (wisnus). Perpaduan potensi natural dan cultural 
resources banyak ditemukan di daerah-daerah pedesaan dalam bentuk desa wiata. Daerah-daerah tersebut seperti Desa Sungai Nyalo (Kabupaten Pesisir Selatan), Desa Taman Sari (Kabupaten Banyuwangi), Desa Seigentung (Kabupaten Gunung Kidul), Desa Waturaka (Kabupaten Ende), dan Desa Bontagula (Kabupaten Bontang) (Good News From Indonesia, 2017). Ketika potensi natural dan cultural resources ada di pedesaan, pengelola potensi tersebut adalah masyarakat yang mendiami daerah tersebut. Menurut pendapat Beeton (2006) dan Junaidi (2017) dalam (Junaid dan Salim, 2019:1), menjadikan masyarakat lokal sebagai pelaku utama dalam kegiatan-kegiatan kepariwisataan disebut dengan pariwisata berbasis masyarakat (community based tourism).

Banyak daerah-daerah di Indonesia yang memiliki potensi natural dan cultural resources yang dapat dikembangkan sebagai daerah wisata. Kementerian Pariwisata (Kemenpar) bersama-sama dengan Kementrian Koperasi dan Usaha Kecil dan Menengah (Kemenkop dan UKM) dan Kementrian Desa Pembangunan Daerah Tertinggal dan Transmigrasi (Kemendes PDTT) mengembangkan 2000 desa wisata sampai tahun 2019 sebagai daerah wisata (Tim Percepatan Wisata Desa dan Kota, 2017). Untuk mencapai target tersebut membutuhkan kerjakeras, karena belum tertanam pemahaman kesemua masyarakat untuk mengelola potensi natural dan cultural resources melalui kegiatan pariwisata. Banyak daerah memiliki potensi pariwisata namun belum dikelola masyarakat lokal dengan baik. Dampaknya potensi pariwisata hanya menjadi kebanggan, tidak memberikan manfaat ekonomi bagi masyarakat lokal. Diperlukan lembaga atau organisasi bentukan masyarakat sebagai wadah partisipasi dalam memaksimalkan potensi pariwisata suatu daerah. Tidak sebatas comummunity based tourism, perlu dibentuk lembaga atau organisasi (community group).

Comummunity based tourism yang berada dalam community group memiliki tujuan bersama yang akan dicapai dan dijabarkan dalam program-program kerja. Untuk mencapai tahapan tersebut comummunity based tourism harus memiliki kemampuan manajemen organisasi. Menurut Thoha (2008: 204) manajemen organisasi disebut dengan pembinaan organisasi, yaitu usaha terencana dari semua aspek untuk meningkatan efektifitas dan kesehatan organisasi dengan mengintervensi setiap proses organisasi dengan mengunakan ilmu pengetahuan dan teknologi. Yang terjadi adalah masalah rendahnya kemampuan manajemen organisasi comummunity based tourism. Mereka adalah perkumpulan masyarakat yang memiliki semangat untuk mengembangkan industri pariwisata. Namun tidak memiliki sumber daya yang mendukung untuk digunakan mewujudkan tujuan tersebut. Rahayu, Dewi, dan Fitriana (2016:12) berpendapat, yang menghambat comummunity based tourism dalam mengembangkan industri pariwisata adalah kurangnya sumber dana, kurangnya kualitas sumber daya manusia, kurangnya inovasi dan kreasi, dan kurangnya dukungan pihak swasta. 
Rahayu dkk tidak menyebutkan ketidak adaan dukungan pihak pemerintah sebagai penghambat comummunity based tourism, padahal pemerintah memiliki andil yang cukup besar dalam mempengaruhi perkembangan industri pariwisata. Namun kembali lagi, karena pengembangan industri pariwisata berdasarkan comummunity based tourism dalam community group seharusnya tidak tergantung pada dukungan pihak swasta dan/atau pemerintah. Ketika comummunity based tourism sudah mapan dalam bentuk community group dan mampu menjalankan manajemen organisasi dengan sendirinya investor akan masuk, baik itu dari pemerintah maupun swasta. Community group disini tidak sebatas organisasi masyarakat yang tidak terikat hukum seperti paguyuban. Community group adalah kelembagaan mapan yang memiliki hukum yang mengikat seperti Badan Usaha Milik Desa (BUMDes). Seperti Desa Karangrejo (Indonesia) yang kalah karena dikelola secara swadaya masyarakat dibandingkan dengan Sierra Norte (Mexico) yang dikelola secara community group dalam kategori most beautiful villages in the world tahun 2017, untuk lebih lengkap lihat tabel 1.

Tabel 1 Perbandingan Desa Karangrejo dengan Sierra Norten

\begin{tabular}{|c|l|l|l|}
\hline No. & \multicolumn{1}{|c|}{ Dimensi } & \multicolumn{1}{|c|}{ Indonesia } & \multicolumn{1}{c|}{ Mexico } \\
\hline 1. & Destinasi & \multicolumn{1}{|c|}{} \\
& & $\begin{array}{l}\text { Rahmad Azhar,National Geographic } \\
\text { Indonesia } \\
\text { Desa Karangrejo }\end{array}$ & Ieirona ,https://www.tripadvisor. com.sg \\
\hline 2. & $\begin{array}{l}\text { Jumlah Wisatawan } \\
\text { 2016 }\end{array}$ & $\begin{array}{l}\text { 325.303 wisatawan } \\
\text { Sierra Norten }\end{array}$ \\
\hline 3. & Daya Tarik Utama & $\begin{array}{l}\text { Sunset, suasana perdesaan, area } \\
\text { pertanian, budaya, panjat tebing } \\
\text { watu sumurup, hutan rakyat, } \\
\text { cagar budaya, camping }\end{array}$ & $\begin{array}{l}\text { Sunset, hiking, berkuda, hutan } \\
\text { montain biking }\end{array}$ \\
\hline 4. & Aksesibilitas & $\begin{array}{l}\text { Jarak tempuh sekitar 5 jam 40 } \\
\text { menit dari pusat Kota Yogyakarta } \\
\text { (230 KM) }\end{array}$ & $\begin{array}{l}\text { 2 jam 57 menit dari kota Mexico } \\
(162,7 \text { KM) }\end{array}$ \\
\hline 5. & Amenitas & Homestay, souvenir shop & Homestay, souvenir shop \\
\hline 6. & Branding/award & $\begin{array}{l}\text { - } \\
\text { Tourism for Tomorrow Award } \\
\text { kategory Community tahun 2016 }\end{array}$ \\
\hline 7. & Pengelolaan & $\begin{array}{l}\text { Masyarakat } \\
\text { Community Grounp }\end{array}$ \\
\hline
\end{tabular}

Sumber: Tim Percepatan Wisata Desa dan Kota, 2017 
Berdasarkan tabel di atas jumlah kunjungan dan keragaman aktivitas Desa Wisata Karangrejo lebih terdepan dibandingkan dengan Sierra Norte. Kelemahan adalah di aksebilitas dan jarak tempuh yang lebih lama serta kekuatan branding dan pengelolaan community based. Aksebilitas dan jarak tempuh bukan masalah yang krusial, karena dengan kekuatan obyek wisata mampu menarik animo wisatawan lebih banyak. Menciptakan wadah comummunity based tourism dalam bentuk community group harus dilakukan, agar pengelolaan obyek wisata lebih efektif dan efisien. Berdasarkan latar belakang masalah di atas, penelitian ini bertujuan untuk menganalisis community based tourism dalam wadah community group untuk pengembangan industri pariwisata.

\section{METODE}

Penelitian ini merupakan jenis penelitian kualitatif dengan menggunakan pendekatan deskriptif. Objek penelitian adalah community based tourism dalam wadah community group untuk pengembangan industri pariwisata. Sumber data penelitian adalah data sekunder, berupa buku, jurnal, news (cetak/digital), regulation, dan dokumen-dokumen lain yang mendukung. Analisis data menggunakan tahapan pengumpulan data, kondensasi data, penyajian data dan penarikan kesimpulan. Teknik analisis data tersebut meliputi: mengolah dan mempersiapkan data untuk dianalisis, membaca keseluruhan data, memulai me-coding semua data, proses coding untuk mendiskripsikan setting (ranah/tempat), orang (partisipan/informan), kategori, dan tema yang akan dianalisis, penyajian kembali laporan penelitian, dan interpretasi atau memaknai data.

\section{HASIL DAN PEMBAHASAN}

Indonesia kaya akan natural dan cultural resources yang dikembangkan menjadi pariwisata sehingga menarik wisman dan wisnus. Dua daerah di Indonesia yang memadukan wisata natural resources dan cultural resources adalah Provinsi Bali dan Provinsi Daerah Istimewa Yogyakarta. Dua daerah tersebut masih menjadi tujuan favorit bagi wisman dan wisnus untuk traveling mengisi liburan. Industri pariwisata dan industri pendukung sudah berkembang di masing-masing daerah tersebut. Lokasi wisata yang dikelola dengan baik, usaha micro kecil dan menengah (UMKM) penyedia souvenir yang beragam, transportasi yang mudah dijangkau, hotel dan restauran yang nyaman dan aman. Jadi, pariwisata sebagai salah satu industri jasa yang memberikan sumbangsih dalam pembangun perekonomian Indonesia. Seperti mengembangankan wilayah, mensejahterahkan masyarakat, berkontribusi dalam devisa dan Produk Domestik Bruto (PDB), melestarikan sumber daya alam dan budaya, maupun dalam meningkatkan rasa cinta tanah air dan perekat persatuan 
bangsa. Kedepan pariwisata Indonesia diperkuat dan dikembangkan menjadi pilar pembangunan perekonomian nasional.

\section{Pengelolaan Wisata Berbasis Community Based Tourism}

Masyarakat, swasta, dan pemerintah merupakan pihak-pihak yang memiliki peran dan terlibat langsung dalam kegiatan kepariwisataan, untuk lebih lengkap lihat gambar 1. Masing-masing pihak tersebut harus memiliki keseimbangan antara satu dengan yang lain. Dulu yang terjadi, kebanyakan peran masyarakat dikesampingkan dari kegiatan kepariwisataan. Tetapi, akhir-akhir ini sudah banyak kegiatan kepariwisataan yang sadar akan pentingnya melibatkan masyarakat. Murphy (1998), Dawyer, Forsyth, dan Dwyer (2010) dalam Sunaryo (2013:219) berpendapat, untuk membangun kepariwisataan harus berupa suatu kegiatan yang berbasis masyarakat. Obyek wisata, baik dalam bentuk natural resources dan/atau cultural resources yang ada pada suatu daerah, masyarakat daerah tersebut yang harus menjadi penggerak utama dalam kegiatan kepariwisataan. Dengan begitu masyarakat mampu mengembangkan dan memaksimalkan nilai manfaat sosial dan ekonomi dari kegiatan kepariwisataan yang mereka kelola. Dalam pembangunan kepariwisataan yang berdasarkan masyarakat, strategi tersebut dikenal dengan istilah community based tourism.

Community based tourism dapat terwujud apabila didukung oleh partisipasi masyarakat. Partisipasi masyarakat bisa ditumbuhkan dari dalam masyarat itu sendiri atau dorongan dari pihak luar. Seperti Desa Wisata Bangun (Kabupaten Trenggalek), partisipasi tumbuh dari dalam masyarakatnya sendiri. Partisipasi tersebut disebut sebagai partisipasi spontan (spontaneous participation). Masyarakat lokal sadar bahwa Desa Bangun memiliki peluang untuk dikembangkan sebagai desa wisata (Rizkianto, 2018:24). Berbeda dengan Kabupaten Kulon Progo, pemerintah kabupaten memfasilitasi desa dan masyarakat untuk mengembangkan wisata berbasis community based tourism. Pengembangan wisata dirumuskan melalui forum focus group discussion (FGD) diantara Pemerintah Kabupaten Kulonprogo, Non Governmental Organization (NGO’s), pusat studi pariwisata, ahli kepariwisataan perguruan tinggi, swasta, dan kelompok sadar wisata bersama-sama 11 desa wisata yang dikembangkan (Rahayu, Dewi, dan Fitriana, 2016:10-12). Dengan berpartisipasi dalam kegiatan kepariwisataan, masyarakat secara mandiri mengembangkan potensi ekonomi, meningkatkan harkat dan martabat, rasa percaya diri dan harga diri dan tertatanya natural dan cultural resources. 


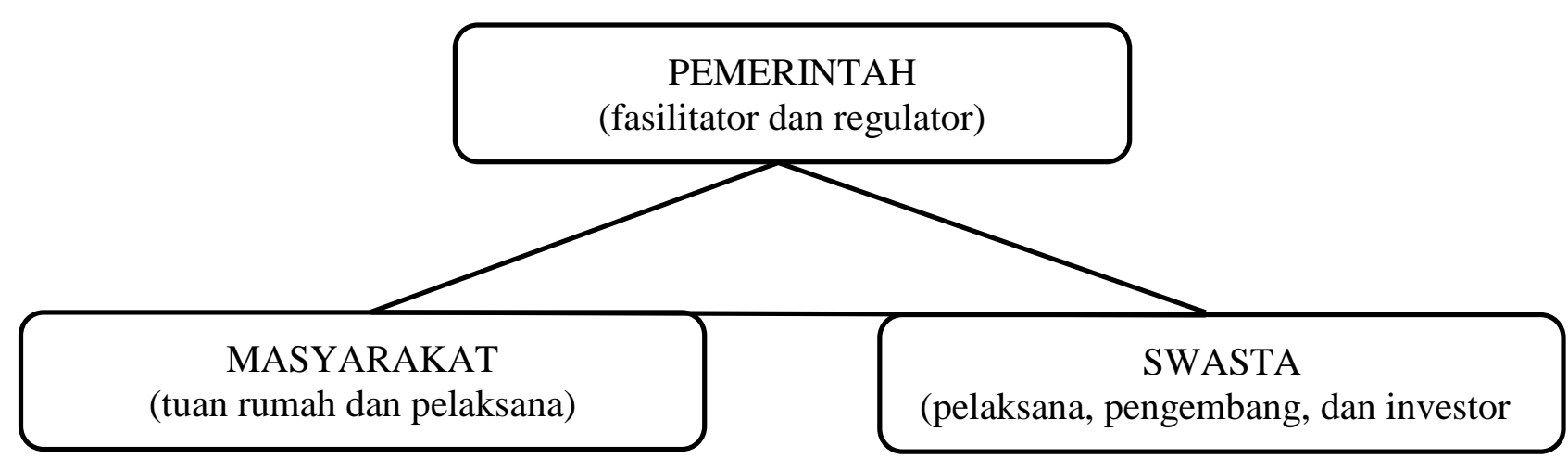

Sumber: diadaptasi dari Wearing, 2001

Gambar 1 Pemangku Kepentingan dalam Kegiatan Kepariwisataan

Partisipasi masyarakat dapat dimunculkan pada setiap proses pembangunan kepariwisataan yang mengadopsi community based tourism. Terdapat tiga tahapan proses pembangunan kepariwisataan, tahap perencanaan, tahap implementasi, dan tahap evaluasi. Partisipasi masyarakat terdapat pada masing-masing tahapan tersebut dan bisa dilihat apakah benar-benar partisipasi masyarakat tersebut dilibatkan dalam pembangunan kepariwisataan atau tidak. Untuk menilai partisipasi masyarakat pada proses perencanaan, dengan cara menilai keterlibatan masyarakat dalam mengidentifikasi masalah, perumusan tujuan, dan pengambilan keputusan dalam pembangunan kepariwisataan. Pada proses implementasi dengan cara menilai keterlibatan masyarakat dalam mengelola obyek wisata dan usaha-usah pendukung kepariwisataan seperti penginapan, rumah makan, pemandu wisata, dan lain-lain. Sedangkan partisipasi masyarakat pada proses evaluasi, masyarakat mampu membentuk tim pengawas dan di dalam tim tersebut dilibatkan masyarakat setempat berseta wewenang yang dimiliki.

Menurut Hudson dan Timothy dalam Sunaryo (2013:139) community based tourism adalah pelibatan dan pendampingan masyarakat untuk membela kepentingan masyarakat tersebut agar memperoleh manfaat. Termasuk kelompok lain yang memiliki minat kepada kepariwisataan, dengan pengelolaan pariwisata untuk mewujudkan kesejahteraan masyarakat setempat. Sedangkan menurut Suansri (2003:14) mendefinisikan community based tourism sebagai wujud perhatian yang kritis pada pembangunan pariwisata yang seringkali mengabaikan hak masyarakat lokal didaerah tujuan wisata. Ada tiga prinsip pokok dalam strategi pembangunan kepariwisataa yang berbasis community based tourism. Pertama, melibatkan masyarakat dalam pengambilan keputusan. Kedua, masyarakat dipastikan mendapat manfaat. Ketiga, pemberian edukasi kepariwisataan kepada masyarakat. Dengan implementasi community based tourism, masyarakat mendapatkan keuntungan materiil lebih dari 
kegiatan kepariwisataan. Disamping materiil juga memperhatikan aspek keberlanjutan lingkungan, sosial, dan budaya.

Perwujudan dari konsep community based tourism yang paling mungkin saat ini adalah desa wisata. Desa wisata dikelola oleh masyarakat desa yang berada diwilayah obyek wisata tersebut. Sumber daya manusia pengelola desa wisata tersebut berkembang bersama-sama untuk mengembangkan potensi natural dan cultural resources. Basis konsep pengembangan wista di Indonesia dikategorikan menjadi tiga. Pertama: nature sebesar 35\%, kedua: culture sebesar 60\%, dan ketiga: manmade sebesar 5\%. Culture di breakdown menjadi wisata budaya, sejarah, dan religi (20\%), wisata kota dan desa (35\%), dan wisata kuliner dan belanja (45\%). Wisata kota dan desa di bagi: wisata perkotan (55\%), pengembangan wisata fotografi arsitektural visit, reunion clubbing, dan belanja. Wisata perdesaan (45)\%, pengembangan wisata live-in,tradisional village, dan mengunjungi saudara/rekan,(Tim Percepatan Wisata Desa dan Kota, 2017). Dengan mengunakan konsep pembangunan wisata di atas, Pemerintah Indonesia melalui Kementerian Pariwisata menargetkan 20 juta wisatawan asing pada tahun2019.

Menurut pendapat Inskeep (1991) dalam Sidiq dan Resnawaty (2017: 39) desa wisata adalah bentuk wisata dimana sekelompok kecil wisatawan tinggal di dalam atau di dekat kehidupan tradisional atau di desa-desa terpencil dan mempelajari kehidupan desa dan lingkungan setempat. Sedangkan menurut Nuryanti (1992) dalam Sidiq dan Resnawaty (2017: 40) desa wisata merupakan bentuk integrasi antara atraksi, akomodasi, dan fasilitas pendukung yang disajikan dalam suatu struktur kehidupan masyarakat yang menyatu dengan tata cara dan tradisi yang berlaku. Pengembangan desa wisata dimulai dari kemampuan masyarakat desa untuk mengelola potensi natural resources dan/atau cultural resources menjadi obyek wisata. Masyarakat kemudian secara bertahap berusaha untuk melengkapi dan meningkatkan fasilitas wisata untuk memenuhi kebutuhan wisatawan. Hal penting yang harus dimiliki desa wisata adalah kemampuan untuk memberikan pengalaman kepada wisatawan rasa hidup seperti masyarakat lokal. Akomodasi tinggal dirumahrumah warga dan atraksi aktif yang bisa dicoba wisatawan, seperti upacara adat.

Menurut pendapat Pantiyana (2011: 1), dalam mengembangkan desa wisata memiliki nilai tambah seperti: Pertama, penduduk desa sebagai pelaku wisata dengan menyediakan tempat menginap, makanan dan minuman, jasa laundry, jasa mobilitas. Kedua, meningkatkan konsumsi produk lokal (sayuran, buah, seni kerajinan, makanan khas) sehingga mendorong kelangsungan usaha lokal. Ketiga, mendorong pemberdayaan tenaga kerja setempat seperti atraksi seni budaya dan kerajinan. Keempat, meningkatkan kesadaran masyarakat akan nilai-nilai natural resources dan cultural resources. Sebagai contoh pengembangan Desa Wisata Nglanggeran dilakukan dengan 
mengupayakan: pengembangan obyek wisata desa, pengembangan amenities (sarana dan prasarana wisata), pengembangan aksebilitas, pemberdayaan masyarakat, menjalin kerjasama dalam pengembangan dan pemberdayaan misalnya dalam hal pemasaran, (Hermawan, 2016: 109). Upaya pengembangan Desa Wisata Nglanggeran tersebut membuahkan penghargaan sebagai desa wisata terbaik nomor satu di Indonesia dan menerima penghargaan Association of Southeast Asian Nations (ASEAN) community based tourism, (http://gunungapipurba.com, 2017).

\section{Melembagakan Community Based Tourism dalam Community Group}

Untuk memaksimalkan pengembangan indusri pariwisata harus melembagakan community based tourism dalam community group. Community based tourism yang terorganisir memiliki visi dan misi untuk dicapai, memiliki program kerja yang jelas, dan pembagian kerja yang terdeskripsi. Sedangkan community based tourism yang tidak berada dalam community group akan menghambat pengembangan industri pariwisata. Seperti kurangnya sumber dana, kurangnya kualitas sumber daya manusia, kurangnya inovasi dan kreasi, dan kurangnya dukungan pihak swasta, (Rahayu, Dewi, dan Fitriana, 2016:12). Community based tourism dalam community group bisa disebut dengan organisasi tata kelola destinasi pariwisata (destination management organization). Sampai sekarang belum banyak yang menggunakan konsep destination management organization dalam pengembangan industri pariwisata. Namun, para akademisi sebenarnya menaruh perhatian pada destination management organization. Karena konsep tersebut sesuai dengan kebanyakan obyek wisata dalam mengembangkan industri pariwisata.

Menurut pendapat Junaid (2015) dan Pearce (2015) dalam Junaid dan Salim (2019: 3), bentuk destination management organization tergantung dari kebutuhan dan kepentingan dari destination management organization tersebut. Sebagai contoh destination management organization dikelola berdasarkan tingkat provinsi, tingkat kabupaten/kota atau dikelola dalam lingkup organisasi yang lebih kecil. Destination management organization bisa juga dikelola berdasarkan tingkat pengelola obyek wisata. Pemilihan tersebut didasarkan pada kebutuhan pengelola untuk memaksimalkan destinasi pariwisata. Untuk tingkat pengelola obyek wisata, cocok dengan konsep community based tourism dalam community group. Karena yang mengelola adalah langsung masyarakat di lokasi obyek wisata sebagai pelaksana kegiatan kepariwisataan. Kedekatan tingkat pengelola dengan obyek wisata akan meningkatkan fleksibelitas pengambilan keputusan dalam pengembangan industri pariwisata. Sedangkan tingkat pengelolaan diatasnya difungsikan sebagai investor, pengembang, fasilitator, atau regulator. 
Longjit dan Pearce (2013) dalam Junaid dan Salim (2019: 3) membagi destination management organization ke dalam tiga kategori. Pertama kategori tujuan, memiliki arti sasaran atau target yang akan dicapai suatu organisasi dalam menjalankan kelompok destination management organization. Sasaran tersebut dituangkan dalam bentuk tujuan yang hendak dicapai pada periode tertentu. Kedua kategori aktifitas, dapat dimaknai sebagai segala usaha, program atau kegiatan yang dijalankan dalam rangka mencapai tujuan destination management organization. Dengan tujuan yang dititikberatkan pada kepentingan bersama (masyarakat) untuk mendapatkan manfaat ekonomi serta pelestarian sumber pariwisata sebagai obyek wisata. Ketiga kategori struktur, merupakan inti dari eksistensi kelompok pengelolaan obyek wisata. Struktur ini tergantung pada kebutuhan lembaga yang sedang atau akan dibentuk.

Fungsi dan peran destination management organization menurut Pearce (2015) dalam Junaid dan Salim (2019: 3) sebagai berikut:

a. Destination management organization akan membantu dalam memasarkan, melakukan branding dan memosisikan (positioning) suatu obyek wisata.

b. Membantu mengembangkan dan/atau mengelola produk-produk olahan (misal: sovenir, makanan khas) yang dimiliki suatu daerah wisata.

c. Melakukan proses perencanaan, implementasi dan evaluasi program kerja yang berkaitan dengan kegiatan kepariwisataan.

d. Mendorong masyarakat untuk berpartisipasi dalam kegiatan kepariwisataan melalui peran fasilitator.

e. Berperan dalam proses pemberian informasi kepada wisatawan serta membantu masyarakat dalam kegiatan sosialisasi dan manfaat pariwisata bagi masyarakat.

Dengan menerapkan destination management organization hubungan stakeholder (pemerintah, swasta, dan masyarakat) terarah. Begitu juga dengan peran dan tanggung jawab masing-masing stakehorder jelas. Gambar 2 di bawah adalah contoh model pengembangan destination management organization sebagai wadah community based tourism.

Konsep community based tourism dalam community group untuk mengembangkan industri pariwisata menempatkan masyarakat sebagai pengelola kepariwisataan. Masyarakat mengelola obyek wisata, seni dan hiburan, sovenir, kuliner, guide, penginapan, transport, dan lain-lain sebagai satu kesatuan. Dalam pengelolaan kepariwisataan masyarakat mendapatkan dukungan investasi dari swasta dan/atau fasilitator dari pemerintah. Konsep community based tourism yang banyak dikembangkan selama ini masih terpisah-terpisah dalam group. Group obyek wisata, group seni dan 
hiburan, dan group-group yang lain masih bekerja sendiri dalam menawarkan produk dan/atau jasa mereka. Group-group tersebut belum menjadi satu community yang terorganisir, memiliki visi dan misi untuk dicapai, memiliki program kerja yang jelas, dan pembagian kerja yang terdeskripsi. Masing-masing group bekerja keras sendiri tanpa tujuan yang terukur, sehingga tidak tercipta efisiensi dan efektivitas pengembangan industri pariwisata. Salah satu cara untuk mengakselerasi mengembangkan industri pariwisata adalah mewadahi community based tourism dalam community group. Salah satu model pengembangan yang bisa digunakan adalah destination management organization seperti di atas.

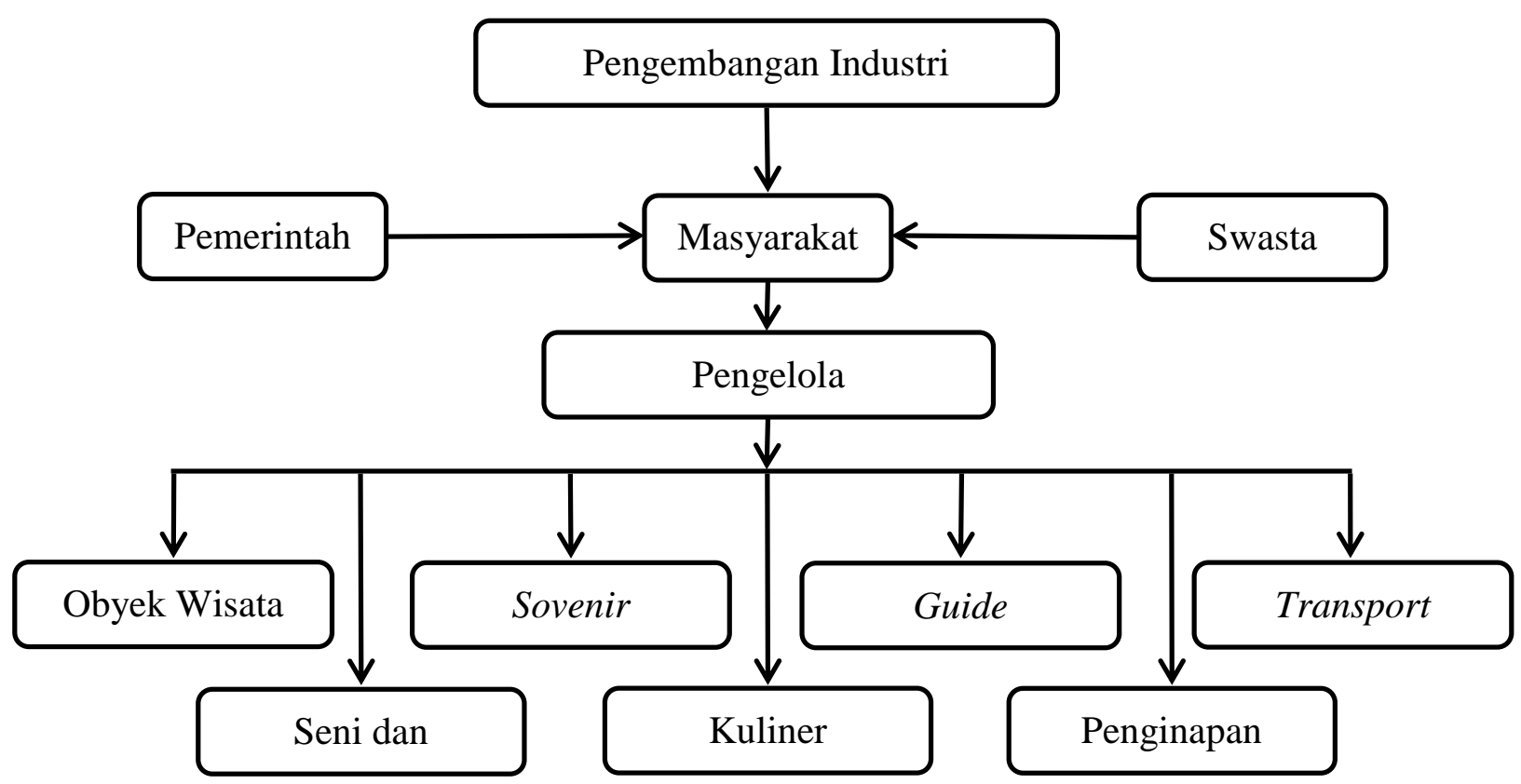

Gambar 2 Konsep Community Based Tourism dalam Community Group

\section{KESIMPULAN}

Berdasarkan pembahasan yang diuraikan di atas peneliti dapat menarik kesimpulan antara lain sebagai berikut:

a. Pengelolaan wisata berbasis community based tourism yang bisa dikembangkan saat ini adalah desa wisata. Obyek wisata yang ada dipedesaan sangat dekat dengan keseharian masyarakat, sehingga mampu menumbuhkan partisipasi masyarakat. Masyarakat sebagai pengelola kepariwisataan mendapatkan keuntungan materiil dan sekaligus menjaga keberlanjutan lingkungan, sosial, dan budaya mereka. 
b. Melembagakan community based tourism dalam community group dapat menggunakan konsep destination management organization untuk pengembangan industri pariwisata. Konsep tersebut meletakan group obyek wisata dan group pendukung kegiatan kepariwisataan lain dalam community. Pengembangan industri pariwisata menggunakan konsep tersebut menciptakan efektifitas dan efisiensi dalam mengelola kepariwisataan.

Implikasi penelitian ini didasarkan pada pembahasan dan kesimpulan di atas antara lain sebagai berikut:

a. Secara teoritis melembagakan community based tourism dalam community group dapat menggunakan konsep destination management organization. Konsep tersebut dapat dikembangkan dan dijadikan kerangka pengembangan industri pariwisata di sektor desa wisata.

b. Secara praktis pengembangan desa wisata menggunakan konsep destination management organization dalam pengelolaan kepariwisataan menciptakan efektifitas dan efisiensi. Karena group obyek wisata dan group pendukung kegiatan kepariwisataan lain dalam satu community.

Dalam penelitian ini peneliti mengikuti prosedur-prosedur penelitian ilmiah, namun tetap terdapat keterbatasan. Keterbatasan penelitian ini, terbatas pada sumber data penelitian sekunder yang bersumber pada penelitian dan dokumen lama. Contoh-contoh kasus juga diambil dari sumber penelitian dan data orang lain. Peneliti belum mampu menemukan kondisi riil perkembangan industri pariwisata di sektor desa wisata. Saran peneliti dalam mengembangkan industri pariwisata di sektor desa wisata dengan menerapkan konsep destination management organization. Konsep tersebut meningkatkan efektifitas dan efisiensi masyarakat dalam mengelola kepariwisataan. Karena group obyek wisata dan group pendukung kegiatan kepariwisataan lain dalam satu community.

\section{DAFTAR PUSTAKA}

Anonim. (2017). Desa Wisata Nglanggeran Menjadi Pemenang ISTA 2017, Maju ke Tingkat Asean. http://gunungapipurba.com/posts/detail/desa-wisata-nglanggeran-menjadi-pemenang-ista2017-maju-ke-tingkat-asean. Dibuka pada 14/08/2019 pukul 14:48.

Hermawan, H. (2016). Dampak Pengembangan Desa Wisata Nglanggeran Terhadap Ekonomi Masyarakat Loka. Jurnal Pariwisata. Volume. 3, No. 2, halaman 105-117.

Junaid, I dan Salim, M.A.M. (2019). Peran Organisasi Tata Kelola dalam Pengelolaan Desa Wisata Nglanggeran, Yogyakarta. Journal of Tourism, Hospitality, Travel and Business Event. Volume 1, No.1, halaman 1-7. 
Pantiyasa, I. W. (2011). Pengembangan Pariwisata Berbasis Masyarakat (Community Based Tourism) dalam Pemberdayaan Masyarakat (Studi kasus di Desa Bedulu, Blah Batuh, Gianyar). Jurnal Ilmiah Hospitality management. Volume 1, No. 2.

Rahayu, S., Dewi, U., dan Fitriana, K.N. (2016). Pengembangan Community Based Tourism Sebagai Strategi Pemberdayaan Ekonomi Masyarakat di Kabupaten Kulon Progo, Daerah Istimewa Yogyakarta. Jurnal Penelitian Humaniora. Volume 21, No. 1, halaman 1-13.

Rizkianto, Neno dan Topowijono. (2018). Penerapan Konsep Community Based Tourism dalam Pengelolaan Daya Tarik Wisata Berkelanjutan (Studi Pada Desa Wisata Bangun, Kecamatan Munjungan, Kabupaten Trenggalek). Jurnal Administrasi Bisnis. Volume 58, No. 2, halaman 20-26.

Sidiq, A.J. dan Resnawaty, R. (2017). Pengembangan Desa Wisata Berbasis Partisipasi Masyarakat Lokal di Desa Wisata Linggarjati Kuningan, Jawa Barat. Universitas Padjadjaran. Volume 4, No. $1,38-44$.

Suansri, P. (2003). Comunity Based Tourism Handbook. Bangkok, Thailand: Responsible Ecological Social Tours (REST) Project.

Sunaryo, B. (2013). Kebijakan Pembangunan Destinasi Pariwisata Konsep dan Aplikasinya di Indonesia. Yogyakarta: Gava Media.

Thoha, Miftah. (2008). Ilmu Administrasi Publik Kontemporer. Jakarta: Kencana Prenada Media Group.

Tim Percepatan Wisata Desa dan Kota. (2017). Pengembangan Desa Wisata : Desa Membangun Desa. Kementerian Pariwisata.

Zulivan, Adriani. (2017). Sepuluh Desa Wisata Terbaik di Indonesia. https://www.goodnewsfromindonesia.id/2017/05/15/10-desa-wisata-terbaik-di-indonesia. Dibuka pada 13/08/2019 pukul 16:01.

\section{UCAPAN TERIMA KASIH}

Penulisan atikel ini hasil dari penelitian dengan sumber data penelitian sekunder. Penulisan artikel ini terwujud dengan bantuan dari pihak Redaksi Efisiensi yang telah menerima artikel ini untuk di terbitkan pada Jurnal Efisiensi. 


\section{PROFIL PENULIS}

Penulis merupakan dosen di Pendidikan Jurusan Administrasi Perkantoran Fakultas Ekonomi Universitas Negeri Yogyakarta. Suhartanto seorang dosen dengan jabatan Tenaga Pengajar memiliki latar belakang pendidikan S1 Administrasi Negara dan S2 Ilmu Administrasi (Administrasi dan Kebijakan Pajak). 